\title{
PENGARUH PELATIHAN SHALAT UNTUK MENURUNKAN PROKRASTINASI AKADEMIK PADA MAHASISWA
}

\section{THE EFFECT OF SHALAT'S TRAINING TO DECREASE ACADEMIC PROCRASTINATION ON UNIVERSITY STUDENT}

\author{
Muhamad Fauzan Azima \\ Nita Trimulyaningsih \\ Uly Gusniarti \\ Fakultas Psikologi dan Ilmu Sosial Budaya, Universitas Islam Indonesia Yogyakarta \\ Email: ozanazima@yahoo.com
}

\begin{abstract}
As the purpose of this study was to investigate the effect of shalat's training to lower on student academic procrastination. The hypothesis is no effect of a decrease in academic procrastination among students who attend training shalat with students who are not trained to shalat. This study uses pretest and posttest control group design, in which the research subjects are students from various departments at " $Y$ " University in Yogyakarta a total of 8 people, with 4 people in the experimental group and 4 people in the control group. This study uses a scale of academic procrastination compiled by Siswanto (2013). Data were analyzed using non-parametric statistics, the Wilcoxon sign rank test. The results of the research in the experimental group for differences pre and post test obtained value $Z=-0.368, p=0.713$ ( $p>0.05)$. As for differences in pre-test and post-test in the control group, the value of $Z=-1.826, p=0.068(p>0.05)$. It can be concluded that there is no difference in academic procrastination before and after the shalat's training. Thus, the research hypothesis was rejected.
\end{abstract}

Keywords: Academic Procrastination, Shalat's Training

\begin{abstract}
ABSTRAK
Penelitian ini bertujuan untuk mengkaji pengaruh pelatihan shalat terhadap prokrastinasi akademik pada mahasiswa. Hipotesisnya adalah terdapat pengaruh penurunan prokrastinasi akademik antara mahasiswa yang mengikuti pelatihan shalat dengan mahasiswa yang tidak mengikuti pelatihan shalat. Desain penelitian adalah pretest and posttest control group design, dengan subjekmahasiswa dari berbagai jurusan di salah satu universitas swasta di Yogyakarta yang berjumlah 8 orang (4 orang kelompok eksperimen dan 4 orang kelompok kontrol). Alat ukur yang digunakan adalah skala prokrastinasi akademik dari Siswanto (2013) dengan reliabilitas alpha cronbach 0,890. Data dianalisis menggunakan uji Wilcoxon sign rank test. Hasil uji beda pada kelompok eksperimendiperoleh nilai $Z=-0,368$ dengan $p=0,713$ ( $p>0,05)$. Sedangkan pada kelompok kontrol diperoleh nilai $Z=-1,826$ dengan $p=0,068(p>0,05)$. Hasil tersebut menunjukkan tidak ada perbedaan prokrastinasi akademik sebelum dan sesudah mengikuti pelatihan shalat. Dengan demikian, hipotesis penelitian ditolak. Hasil ini akan dibahas lebih lanjut di dalam naskah.
\end{abstract}

Kata kunci: Prokrastinasi Akademik, Pelatihan Shalat 
Saat ini mahasiswa identik dengan sebutan agen of change. Dalam proses perkuliahan mahasiswa akan ditantang dengan berbagai kesibukan perkuliahan, dan jika diabaikan akan mempengaruhi nilai, waktu studi, serta amanah orang tuanya. Hambatan yang sering ditemui dalam perkuliahan adalah penggunaan waktu yang kurang efektif atau sikap suka menunda-nunda pekerjaan yang berkaitan dengan hal-hal akademik, misalnya menunda membuat tugas kuliah, terlambat kuliah, malas membaca, dan menunda untuk belajar.

Fenomena perilaku menunda-nunda pekerjaan ini berisiko merugikan mahasiswa dalam rangkaian proses perkuliah yang akan ditempuh. Menurut Godfrey (Rumiani, 2006), pemanfaatan waktu yang kurang baik dan ketidakdisiplinan berpengaruh pada lamanya masa studi mahasiswa, yang semestinya dapat diselesaikan dalam waktu 4 tahun, terpaksa diperpanjang sampai 7 atau 10 tahun.

Hayyinah (2004) menegaskan, ketika mahasiswa S-1 telah melewati empat tahun masa studinya, maka dapat dikatakan ada indikasi mahasiswa tersebut melakukan prokrastinasi akademik. Menurut Solomon dan Rothblum (Rumiani, 2006), prokrastinasi merupakan kecenderungan untuk menunda dalam memulai, melaksanakan, dan mengakhiri suatu aktivitas. Prokrastinasi yang terjadi dalam lingkungan akademik disebut dengan prokrastinasi akademik.

Milgram, Batin dan Mower (Akinsola dkk., 2007) menyatakan bahwa bentuk umum prokrastinasi akademik di kalangan mahasiswa adalah menunggu sampai menit terakhir untuk menyelesaikan tugas-tugas atau sekedar belajar untuk ujian. Hal ini sejalan dengan yang disampaikan oleh Oweini dan Haraty (Akinsola dkk., 2007) bahwa mahasiswa cenderung lebih sering melakukan prokrastinasi

Hayyinah (2004) menyampaikan bahwa data dari Biro Akademik dan Administrasi Kemahasiswaan (BAAK) di universitas tempat penelitian bahwa pada tahun 2003 menunjukkan terdapat 29,24\% mahasiswa (5655 dari keseluruhan mahasiswa) belum dapat menyelesaikan kuliahnya setelah menjalani masa kuliah selama empat tahun. Berikut Ini data masa studi lulusan setiap angkatan pada masing-masing program studi atau jurusan berdasarkan data akademik universitas pada bulan Maret 2014, yang diambil dari rata-rata masa studi adalah dalam satuan semester. Secara normal masa studi 4 tahun sama dengan 8 semester, namun terdapat faktor lain yang dapat mempengaruhi masa studi yaitu faktor administrasi (kelengkapan berkas untuk 
dinyatakan lulus). Oleh karena itu jika administrasi maka akan dicatat pada mahasiswa terlambat dalam penyelesaian semester berikutnya.

Tabel 1. Data Akademik Masa Studi Lulusan UII Angkatan 2008-2009

Per Maret 2014

\begin{tabular}{|c|c|c|c|}
\hline Tahun & Jurusan & Jumlah lulusan & Rata-rata semester \\
\hline 2008 & Akuntansi & 299 & 9,331104 \\
\hline 2008 & Arsitektur & 97 & 9,773196 \\
\hline 2008 & Ekonomi Islam & 26 & 9,269231 \\
\hline 2008 & Farmasi & 134 & 8,58209 \\
\hline 2008 & Hukum Islam & 9 & 9,444444 \\
\hline 2008 & Ilmu Ekonomi & 49 & 9,346939 \\
\hline 2008 & Ilmu Hukum & 331 & 9,918429 \\
\hline 2008 & Ilmu Kimia & 8 & 9,125 \\
\hline 2008 & Ilmu Komunikasi & 59 & 10,05085 \\
\hline 2008 & Manajemen & 228 & 9,214912 \\
\hline 2008 & Pendidikan Agama Islam & 31 & 8,064516 \\
\hline 2008 & Pendidikan Dokter & 184 & 8,701087 \\
\hline 2008 & Psikologi & 210 & 9,861905 \\
\hline 2008 & Statistika & 8 & 10,375 \\
\hline 2008 & Teknik Elektro & 32 & 9,125 \\
\hline 2008 & Teknik Industri & 114 & 10,42982 \\
\hline 2008 & Teknik Informatika & 245 & 9,236735 \\
\hline 2008 & Teknik Kimia & 15 & 9,466667 \\
\hline 2008 & Teknik Lingkungan & 28 & 10,39286 \\
\hline 2008 & Teknik Mesin & 17 & 9,411765 \\
\hline 2008 & Teknik Sipil & 67 & 11,01493 \\
\hline 2009 & Akuntansi & 259 & 8,930502 \\
\hline 2009 & Arsitektur & 70 & 9,5 \\
\hline 2009 & Ekonomi Islam & 25 & 8,84 \\
\hline 2009 & Farmasi & 111 & 9,36036 \\
\hline 2009 & Hukum Islam & 14 & 8,714286 \\
\hline 2009 & Ilmu Ekonomi & 34 & 7,911765 \\
\hline 2009 & Ilmu Hukum & 223 & 9,560538 \\
\hline 2009 & Ilmu Kimia & 9 & 9,333333 \\
\hline 2009 & Ilmu Komunikasi & 36 & 9,444444 \\
\hline
\end{tabular}




\begin{tabular}{llll}
\hline Tahun & Jurusan & Jumlah lulusan & Rata-rata semester \\
\hline 2009 & Manajemen & 233 & 9,004292 \\
2009 & Pendidikan Agama Islam & 16 & 8,9375 \\
2009 & Pendidikan Dokter & 227 & 7,484581 \\
2009 & Psikologi & 104 & 9,269231 \\
2009 & Statistika & 10 & 8,2 \\
2009 & Teknik Elektro & 5 & 9,6 \\
2009 & Teknik Industri & 55 & 8,836364 \\
2009 & Teknik Informatika & 182 & 9,252747 \\
2009 & Teknik Kimia & 14 & 10 \\
2009 & Teknik Lingkungan & 33 & 10,0303 \\
2009 & Teknik Mesin & 6 & 10 \\
2009 & Teknik Sipil & 51 & 9,921569 \\
\hline
\end{tabular}

Dari data tersebut terlihat bahwa rata-rata mahasiswa di " $Y$ " Indonesia menyelesaikan kuliah dalam kurun 9 sampai 10 semester. Beberapa orang menempuh studi melebihi 10 semester dari waktu tempuh yang seharusnya adalah 8 semester atau empat tahun. Hal ini menunjukkan akan adanya kecenderungan perilaku prokrastinasi akademik.

Menurut Ferrari (Muhid, 2009) prokrastinasi akademik banyak memberikan dampak negatif, dengan melakukan penundaan maka dampaknya banyak waktu yang terbuang. Tugas-tugas menjadi terbengkalai, bahkan bila terselesaikan hasilnya menjadi tidak maksimal. Penundaan juga bisa mengakibatkan seseorang kehilangan kesempatan dan peluang yang datang. Beberapa hasil penelitian menunjukkan bahwa prokrastinasi merupakan salah satu masalah yang menimpa sebagian besar anggota masyarakat secara luas, dan pelajar pada lingkungan yang lebih kecil. Ferrari (Muhid, 2009) juga menambahkan sekitar 25\% sampai dengan 75\% dari pelajar melaporkan bahwa prokrastinasi merupakan salah satu masalah dalam lingkup akademis yang dihadapi. Sejalan dengan hal tersebut Popoola (Asikhia, 2010) menyampaikan bahwa prokrastinasi ini berhubungan dengan prestasi akademis yang buruk.

Selain itu, prokrastinasi juga berpengaruh pada kinerja seseorang di masa depan. Hal ini berkaitan dengan pemanfaatan waktu yang kurang efisien dalam setiap aktivitas yang dilakukan oleh individu yang melakukan prokrastinasi. 
Kemudian, Tondok dkk (2008) menyampaikan bahwa prokrastinator akan mengalami konsekuensi yang kurang menyenangkan yaitu munculnya tekanan psikologis (psychological tention). Oleh karena itu, menurut Sirois dan Pychy (Asikhia, 2010)sebagian besar mahasiswa yang menderita prokrastinasi, menolak menyelesaikan tugas, dan menundanya diwaktu lain justru hanya akan membangkitkan ketegangan dan kecemasan yang dialami.

Solomon dan Rothblum (Tondok dkk, 2008) menyatakan, bahwa suatu penundaan dikatakan sebagai prokrastinasi apabila penundaan itu dilakukan pada tugas yang penting yang kemudian dilakukan secara berulang-ulang secara sengaja, dan menimbulkan perasaan tidak nyaman. Apabila penundaan tersebut terjadi dalam lingkungan akademik, maka dapat terindikasi sebagai prokrastinasi akademik. Covington dan Omelich (Hayyinah, 2004), juga menyampaikan bahwa prokrastinasi akademik merupakan bentuk coping dari mahasiswa untuk mengatasi stres akademik.Perilaku ini biasanya dilakukan pada jenis tugas formal yang berhubungan dengan bidang akademik, misalnya tugas-tugas sekolah atau tugas kursus (Ferraridkk., 1995).
Berdasarkan penelitian Hayyinah (2004) yang berjudul "Religiositas dan Prokrastinasi Akademik pada Mahasiswa", diperoleh hasil, yaitu korelasi negatif yang sangat signifikan antara variabel tingkat religiositas mahasiswa dengan variabel prokrastinasi akademik. Rendahnya religiositas yang dimiliki mahasiswa yang melakukan prokrastinasi akademik, menurut Hayyinah (2004) hal ini tidak terlepas dari cara pandang individu terhadap keberadaan agama yang akhirnya membentuk sikap dalam kehidupannya.

Religiositas yang tinggi akan didapatkan, ketika individu dekat dengan Tuhan, yaitu Allah Subhanahu wa Ta'ala, dengan cara-cara yang sudah diajarkan dalam Islam, salah satunya adalah dengan shalat. Menurut Shihab (Haryanto, 2005) shalat merupakan sarana penting guna mensucikan jiwa dan memelihara ruhani.

Selain itu, shalat juga sebagai sarana yang tepat untuk mendapat pertolongan dari Allah SWT. Sebagaimana firmanNya yang berbunyi :

"Jadikanlah sabar dan shalat sebagai penolongmu. Dan sesungguhnya yang demikian itu sungguh berat, kecuali bagi orang-orang yang khusyuk." (Al Baqarah : 45). 
Shalat merupakan bagian dari rukun Islam ke dua setelah syahadat yang berarti wajib hukumnya untuk dikerjakan. Nasr (Haryanto, 2005) mengungkapkan, bahwa shalat itu adalah tiang agama, serta amal ibadah yang pertama kali ditimbang di akhirat kelak. Shalat mengajarkan untuk berkomitmen yaitu saat Allah SWT memberikan perintah untuk tepat waktu dalam pelaksanaannya, yaitu lima kali sehari, yang meliputi 5 waktu, yaitu Shubuh, Dzuhur, Ashar, Maghrib, dan Isya (Al-lkhwani, 2012). Bila seseorang memulai dari disiplin shalat, makaakan terbiasa melakukan disiplin-disiplin dalam kegiatan lainnya. Shalat sebagai sarana untuk beribadah kepada Allah juga menekankan pada kedisiplinan dalam penggunaan waktu yang dalam pelaksanaannya perlu istiqomah. Dengan adanya kedisiplinan dalam shalat dengan menghindari penundaan, maka akan mengikis perilaku prokrastinasi.

Sebagaimana intervensi dengan menggunakan variabel shalat sebagai modalitas telah digunakan oleh Siswanto (2013) dalam penelitiannya, yang terbukti efektif untuk mengatasi prokrastinasi, karena ditemukan korelasi yang negatif yang sangat signifikan antara kedisiplinan melaksanakan shalat wajib dengan prokrastinasi akademik.
Mengingat pada penelitian shalat dengan prokrastinasi, intervensi yang digunakan sederhana, dengan itu peneliti hendak melakukan pelatihan shalat sebagai sarana intervensi yang lebih mendalam terhadap kecenderungan prokrastinasi pada mahasiswa.

Munandar (2001) menjelaskan pelatihan adalah proses pendidikan jangka pendek yang mempergunakan prosedur sistematis dan terorganisir. Sedangkan shalat secara etimologis adalah do'a, dan secara terminologis adalah ucapan dan perbuatan tertentu yang diawali dengan takbir dan diakhiri dengan salam (Al Fauzan, 2005).

Pelatihan shalat adalah proses pendidikan jangka pendek yang mempergunakan prosedur yang sistematis dan terorganisir sebagai sarana untuk mengingat Allah melalui ibadah shalat, guna memperoleh kebahagiaan dan kebermaknaan dalam hidup.

Berdasarkan uraian di atas, maka hipotesis yang diajukan dalam penelitian ini adalah ada penurunan prokrastinasi akademik antara mahasiswa yang mengikuti pelatihan shalat dengan mahasiswa yang tidak mengikuti pelatihan shalat. Mahasiswa yang mengikuti pelatihan shalat tingkat prokrastinasi akademiknya lebih rendah dibanding mahasiswa yang tidak ikut pelatihan shalat. 


\section{METODE PENELITIAN}

\section{Desain Penelitian}

Metode penelitian ini merupakan metode penelitian eksperimental, dengan variabel tergantung prokrastinasi akademik, dan variabel bebas pelatihan shalat. Desain eksperimen yang digunakan dalam penelitian ini adalah pretest andposttest control group design. Menurut Latipun (2010), pretest and posttest control group design merupakan desain eksperimen yang dilakukan dengan jalan melakukan pengukuran atau observasi awal sebelum perlakuan dan setelah perlakuan pada kelompok eksperimen dan kelompok kontrol.

Tabel 2. Rancangan Eksperimen

\begin{tabular}{cccc}
\hline Kelompok & Prates & Perlakuan & Pascates \\
\hline KE & $Y_{1}$ & $X$ & $Y_{2}$ \\
KK & $Y_{1}$ & $-X$ & $Y_{2}$ \\
\hline
\end{tabular}

Keterangan :

$\mathrm{KE} \quad=$ Kelompok Eksperimen

KK $=$ Kelompok Kontrol

$\mathrm{Y}_{1} \quad=$ Pengukuran prates

$\mathrm{Y}_{2} \quad=$ Pengukuran pascates

$\mathrm{X}=$ Perlakuan

$-\mathrm{X} \quad=$ Tanpa perlakuan

\section{Subjek Penelitian}

Subjek penelitian ini memiliki beberapa kriteria yaitu mahasiswa aktif, baik laki-laki maupun perempuan yang masih menempuh pendidikan S1 lebih dari 4 tahun atau lebih dari 8 semester atau berkisar angkatan 2008, 2009, dan 2010 dari berbagai jurusan yang ada di "Y" Indonesia, berusia antara 22-25 tahun. Bersedia mengikuti pelatihan dan mempraktekkan shalat sebagaimana yang diterima saat pelatihan. Untuk kelompok eksperimen yang akan mengikuti pelatihan shalat, akan dipilih berdasarkan skor pre test dari skala prokrastinasi akademik subjek yang berada pada tingkat sedang dan tinggi. 


\section{Metode Pengumpulan Data}

Metode penelitian ini merupakan metode penelitian eksperimental, dengan variabel tergantung prokrastinasi akademik, dan variabel bebas pelatihan shalat. Desain eksperimen yang digunakan dalam penelitian ini adalah pretest and posttest control group design. Kemudian metode pengumpulan data yang digunakan adalah metode skala untuk mendapatkan jenis data kuantitatif, serta ditambah dengan metode observasi dan wawancara. Skala yang digunakan adalah skala prokrastinasi akademik oleh Siswanto (2013) meliputi aspek yang dikemukakan oleh Schouwenberg (Ferrari dkk., 1995), yakni penundaan untuk memulai maupun menyelesaikan tugas yang dihadapi, keterlambatan dalam mengerjakan tugas, kesenjangan waktu antara rencana dan kinerja, melakukan aktivitas lain yang lebih menyenangkan dari pada melakukan tugas yang harus dikerjakan, kemudian aspek dari Surijah dan Tjundjing (Siswanto, 2013), yakni emotional distress, serta perceived ability atau keyakinan terhadap kemampuan diri.

\section{Prosedur Intervensi}

Prosedur eksperimen pada penelitian ini terbagi menjadi empat bagian, yakni yang pertama persiapan penelitian yang terdiri dari, analisis kebutuhan, penyusunan modul pelatihan, alat atau materi, seleksi trainer dan observer, serta seleksi peserta pelatihan, kemudian yang ke dua pengukuran awal (pre test), selanjutnya yang ke tiga adalah pelaksanaan penelitian, dan yang terakhir adalah pengukuran akhir (post test).

Pelaksanaan penelitian dibagi menjadi dua kelompok, yaitu kelompok eksperimen dan kelompok kontrol. Kelompok eksperimen mendapat perlakuan berupa pelatihan shalat, sedangkan kelompok kontrol tidak mendapat perlakuan. Modul pelatihan shalat berisi materi yang disusun berdasarkan teori dan aspek-aspek shalat yang penulis simpulkan dari Al Badr (2013), Imam Al Ghazali (Hawwa, 2000), dan Musbikin (2008). Materi sebagai berikut, Jagalah Shalat, Jagalah Shalat, kemudian Menggapai Khusyu', Buanglah Was-was pada Tempatnya, Aplikasi Pemahaman Materi Pelatihan pertemuan I, kemudian Karunia Hanya Milik Allah dan Sifat Shalat Nabi Shalallahu 'Alaihi wa Sallam.

Pelatihan ini dilakukan dalam dua kali pertemuan dengan alokasi waktu untuk pertemuan pertama adalah 150 menit dan pertemuan dua adalah 130 menit, sehingga waktu total keseluruhan adalah 280 menit. 


\section{Metode Analisis Data}

Data dianalisis menggunakan jenis statistik non parametrik, jenis uji statatistik menggunakan Wilcoxon sign rank test dengan dua sampel berhubungan (paired). Penelitian ini menggunakan pogram analisis statistik SPSS 18.00 for Windows.

\section{HASIL PENELITIAN}

\section{Deskripsi Data}

Gambaran mengenai skor minimal, skor maksimal, rerata dan standar deviasi yang diperoleh melalui uji statistik tercantum pada tabel 2 .

Tabel 3. Deskrpsi Data Penelitian

\begin{tabular}{|c|c|c|c|c|c|c|c|c|}
\hline \multirow[b]{2}{*}{ Variabel } & \multicolumn{4}{|c|}{ Hipotetik } & \multicolumn{4}{|c|}{ Empirik } \\
\hline & $\begin{array}{c}X \\
\min \end{array}$ & $\begin{array}{c}\mathrm{X} \\
\max \end{array}$ & Mean & SD & $\begin{array}{c}\mathrm{X} \\
\mathrm{min}\end{array}$ & $\begin{array}{c}\mathrm{X} \\
\max \end{array}$ & Mean & SD \\
\hline $\begin{array}{c}\text { Prokrastinasi } \\
\text { Akademik }\end{array}$ & 27 & 108 & 67,5 & 13,5 & 47 & 79 & 64,82 & 8,266 \\
\hline
\end{tabular}

Selanjutnya berdasarkan hasil tinasi akademik subjek yang adapat analisis didapatkan kategorisasi prokras- dilihat pada tabel 3.

Tabel 4. Kategorisasi Subjek Prokrastinasi Akademik

\begin{tabular}{cccc}
\hline Skor & Kategorisasi & Frekuensi & Persentase \\
\hline$X<56,55$ & Rendah & 0 & $0 \%$ \\
$56,55 \leq X<73,09$ & Sedang & 4 & $50 \%$ \\
$X>73,05$ & Tinggi & 4 & $50 \%$ \\
\hline Jumlah & & $\mathbf{8}$ & $\mathbf{1 0 0} \%$ \\
\hline
\end{tabular}

\section{Hasil Uji Asumsi}

Uji asumsi yang digunakan dalam penelitian ini adalah analisis sample independent (eksperimen-kontrol) dengan menggunakan analisis Mann Whitney, yaitu jenis statistik non parametrik.
Analisis ini digunakan untuk menguji perbedaan nilai pre test pada kelompok eksperimen dan kontrol, perbedaan nilai post test pada kelompok eksperimen dan kontrol serta perbedaan gain score pada kelompok eksperimen dan kontrol. Hasil 
yang diperoleh dari analisis menunjukkan nilai $Z=-0,289$ dengan $p=0,773$ $(p>0,05)$. Hal ini menunjukkan bahwa tidak ada perbedaan nilai prates antara kelompok eksperimen dan kelompok kontrol.

\section{Hasil Uji Hipotesis}

Untuk analisis sampel berhubungan (pretest-posttest) dalam penelitian ini menggunakan uji Wilcoxon, yaitu teknik analisis yang dilakukan untuk menguji beda antara prates dan pascates, baik pada kelompok eksperimen maupun kelompok kontrol, pada data yang menggunakan statistik non parametrik. Berdasarkan hasil analisis data, diperoleh nilai Z untuk perbedaan pre test dan post test pada kelompok eksperimen adalah sebesar $Z=-0,368$ dengan $p=0,713$ $(p>0,05)$. Sedangkan untuk perbedaan prates dan pascates pada kelompok kontrol, diperoleh nilai $Z=-1,826$ dengan $p=0,068 \quad(p>0,05)$. Berdasarkan hal tersebut, diperoleh kesimpulan bahwa tidak adaperbedaan prates dan pascates yang signifikan pada kelompok eksperimen, begitupula pada kelompok kontrol juga tidak ada perbedaan prates dan pascates yang signifikan.Oleh karena itu hipotesis ditolak.

\section{Hasil Analisis Kualitatif}

Berikut adalah analisis kualitatif para subjek, mulai dari subjek satu hingga empat yang masuk dalam kelompok eksperimen yang disajikan dalam bentuk tabel yang memuat kondisi subjek dari sebelum pelatihan, sesudah pelatihan, dan pemahaman yang subjek dapatkan ketika mengikuti pelatihan. Hal tersebut dapat dilihat pada tabel 4 sampai dengan tabel 7 .

Tabel 5. Evaluasi kondisi subjek 1

\begin{tabular}{|c|c|c|}
\hline Sebelum Pelatihan & Sesudah Pelatihan & Pemahaman \\
\hline $\begin{array}{l}\text { a. } \\
\text { Subjek kurang } \\
\text { termotivasi dan } \\
\text { terkadang ada } \\
\text { rasa malas } \\
\text { untuk belajar, } \\
\text { dan } \\
\text { mengerjakan }\end{array}$ & $\begin{array}{l}\text { a. } \\
\text { Subjek lebih } \\
\text { termotivasi untuk } \\
\text { banyak belajar lagi, } \\
\text { baik dalam shalat } \\
\text { dan kegiatan sehari- } \\
\text { harinya. }\end{array}$ & $\begin{array}{l}\text { Subjek memperoleh pemahaman } \\
\text { tentang shalat, yang membuatnya } \\
\text { untuk terus belajar. Lebih ikhlas } \\
\text { dalam menjalankan sesuatu, yang } \\
\text { sebelumnya subjek memiliki } \\
\text { persepsi yang negatif atau } \\
\text { khawatir akan suatu hal terutama }\end{array}$ \\
\hline
\end{tabular}


sesuatu.

b. Khawatir akan skripsi yang belum selesai. b. Mengetahui manfaat yang dirasakan dari shalat, dan yang sudah ia terapkan. skripsi, kemudian ia sadar dan

berusaha untuk menerima dan ikhlas, melalui manfaat dan praktek shalat yang ia terapkan.

Tabel 6. Evaluasi kondisi subjek 2

\begin{tabular}{lll}
\hline Sebelum Pelatihan & Sesudah Pelatihan & Pemahaman \\
\hline Belum bisa fokus, & Subjek merasa lebih & Subjek memahami keadaannya, \\
karena kurang & baik dari sebelumnya, & dan berusaha untuk terus \\
motivasi. & ditambah adanya & memotivasi dirinya, melalui apa \\
& pengetahuan baru yang & yang ia dapatkan pada pelatihan \\
& didapat, dan secara & shalat, walau belum maksimal. \\
& sadar ingin & \\
& mempraktekkan apa & \\
& yang didapatkan di \\
& materi. Hanya saja \\
& belum maksimal karena \\
& masalah motivasi diri. \\
\hline
\end{tabular}

Tabel 7. Evaluasi kondisi subjek 3

\begin{tabular}{lll}
\hline Sebelum Pelatihan & Sesudah Pelatihan & Pemahaman \\
\hline Subjek masih & Subjek mengungkapkan & Subjek memahami hakikat dari \\
berkutat pada & ada ilmu baru yang bisa & shalat adalah khusyu', dengan \\
beberapa kesibukan & diperoleh, dan bisa & mengikhlaskan segala hal kepada \\
yang membuatnya & lebih ikhlas daripada & Allah Subhanahu wa Ta'ala, yang \\
belum bisa ikhlas. & sebelumnya. & harus diterapkan dalam \\
& & kehidupan sehari-hari.
\end{tabular}


Tabel 8. Evaluasi kondisi subjek 4

\begin{tabular}{lll}
\hline Sebelum Pelatihan & Sesudah Pelatihan & Pemahaman \\
\hline Subjek belum bisa & Subjek mendapat & Subjek sadar, belum sepenuhnya \\
mengatur waktu & pengetahuan yang lebih & bisa menerapkan semua yang ia \\
dengan baik, & tentang shalat dan & dapatkan dalam pelatihan shalat. \\
dikarenakan & manfaatnya dalam & Namun subjek sudah merasa \\
banyak rencana & kehidupan sehari-hari, & lebih tenang dan bagaimana \\
dan pikiran dalam & subjek merasa lebih & meniatkan itu semua agar \\
kesibukannya. & tenang dan lebih & menjadi motivasi untuk dirinya. \\
& termotivasi, namun juga & \\
& harus dikembalikan & \\
& pada niat dalam diri. & \\
\hline
\end{tabular}

Dari uraian analisa kualitatif dalam tabel di atas, dapat dilihat pengaruh pelatihan shalat yang dirasakan oleh subjek penelitian.Meliputi beberapa hal yang dirasakan subjek, diantaranya munculnya perasaan tenang dan nyaman, lebih ikhlas, dan lebih termotivasi dalam melakukan suatu hal, baik dalam lingkup akademik ataupun lingkup sehari-hari.

\section{PEMBAHASAN}

Penelitian ini bertujuan mengetahui pengaruh pelatihan shalat untuk menurunkan prokrastinasi akademik pada mahasiswa. Dari hasil pelatihan shalat yang diberikan diperoleh hasil, bahwa pelatihan shalat tidak memiliki pengaruh untuk menurunkan prokras- tinasi akademik. Berdasarkan pada hasil analisis kuantitatif diketahui tidak ada perubahan prokrastinasi akademik yang signifikan pada kedua kelompok, di mana pada kelompok eksperimen diperoleh nilai Z untuk perbedaan pre test dan post test pada kelompok eksperimen adalah sebesar $Z=-0,368$ dengan $p=0,713(p>0,05)$. Sedangkan untuk perbedaan prates dan pascates pada kelompok kontrol, diperoleh nilai $Z=-1,826$ dengan $p=0,068(p>0,05)$.

Adapun analisis tambahan pada penelitian ini berupa analisis setiap sesi pelatihan dan analisis masing-masing individu, dalam hal ini berdasarkan observasi dan wawancara pada subjek penelitian.Dari analisis tiap sesi pelatihan diketahui adanya interaksi yang efektif 
antara subjek dan trainersaat pelatihan berlangsung. Hal ini dapat dilihat dari antusiasme yang ditunjukkan subjek dan feedbackyang dimunculkan oleh subjek ketika berdiskusi dengan trainer terkait materi-materi shalat yang diberikan selama pelatihan berlangsung. Sedangkan dari analisis masing-masing individu, ditemukan satu subjek yang mengalami penurunan skor prokrastinasi akademik, dan tiga subjek lainnya mengalami kenaikan skor prokrastinasi akademik. Selain itu, ditemukan pula bahwa secara individu, subjek memperoleh manfaat dari pelatihan shalat yang kemudian diterapkan dalam shalat, yaitu membuat tenang dan nyaman, lebih ikhlas dan lebih termotivasi.

Hasil penelitian yang menunjukkan tidak adanya pengaruh yang signifikan antara pelatihan shalat untuk menurunkan prokrastinasi akademik pada mahasiswa, bertolak belakang dengan hasil penelitian sebelumnya yang dilakukan Siswanto (2013) dengan judul “Hubungan Antara Kedisiplinan Melaksanakan Sholat Wajib Dengan Prokrastinasi Akademik Pada Mahasiswa" di mana diperoleh hasil, bahwa ada hubungan negatif yang sangat signifikan antara kedisiplinan melaksanakan shalat wajib dengan prokrastinasi akademik pada mahasiswa. Hal ini juga tidak sejalan dengan pendapat Haryono (Siswanto, 2013) bahwa menunaikan shalat tepat waktu berarti melatih diri untuk disiplin. Bila dimulai dari disiplin shalat, maka seseorang akan terbiasa melakukan disiplin-disiplin dalam kegiatan lainnya. Shalat tepat waktu bisa menjadi ukuran disiplin bagi seorang muslim.

Tidak terbuktinya hipotesis penelitian dikarenakan ada beberapa faktor yang mempengaruhi. Pertama, yaitu waktu pemberian skala, di mana jarak prates dan pascates yang terlalu dekat. Menurut Latipun (2010) pengaruh faktor pengujian (testing) dapat terjadi bila dilakukan desain penelitian ulang (pre test-post test),sehingga terjadi kenaikankenaikan skor pascates, karena subjek pernah mengerjakan prates sebelumnya. Oleh karena itu, jika jarak waktu uji awal dengan uji akhir semakin dekat, maka pengaruh faktor pengujian akan semakin tinggi. Hal ini dikarenakan, saat itu subjek masih akan mendapatkan pemahaman baru setelah mendapatkan pelatihan shalat, sehingga baru akan terbentuk sebuah kesadaran yang mungkin tidak akan langsung diwujudkan dalam tindakan nyata. Mengingat antara pelatihan 1 dan 2 selisihnya hanya satu minggu, dan dengan post test berjarak 3 hari, sehingga perubahan ke perilaku nyata, yaitu tidak lagi melakukan prokrastinasi 
akademik masih perlu diamati lebih lanjut dengan alat ukur yang lebih variatif.

Faktor kedua, yaitu pada waktu pengisian skala ada subjek yang terlihat cenderung ingin menjawab skala dengan cepat tanpa membaca pernyataan yang terdapat di dalam dengan teliti.Sebelum pengisian skala, peneliti sudah mengingatkan agar dalam pengisian skala tidak terburu-buru dan tenang. Hal ini tentunya akan menghasilkan jawaban yang kurang menggambarkan diri mereka. Sehingga faktor waktu pengisian skala ini, berpengaruh pada jawaban yang diberikan oleh subjek. Selain itu, pada saat pengisian skala subjek tidak dalam kondisi siap dan tampak kelelahan. Hal ini terlihat dari keadaan beberapa subjek ketika pascates, ada yang baru selesai dari pasar membantu orangtuanya, ada juga yang baru bangun, karena waktu pengisian skala pascates ini adalah pagi pukul 10.00 WIB. Pengambilan waktu ini atas dasar pertimbangan dari peneliti dan persetujuan dari subjek, karena di waktu lain beberapa ada yang tidak bisa mengikuti. Sebagaimana diketahui, kondisi subjek penelitian berpengaruh terhadap hasil penelitian. Ketika subjek mengalamai kelelahan maka itu akan sangat berpengaruh pada hasil penelitian.
Faktor ketiga, yaitu alat ukur berupa skala prokrastinasi akademik baru mengukur sebatas pemahaman siswa pada tataran kognitif sehingga peneliti juga belum dapat melihat gambaran perubahan pada prokrastinasi akademik yang dialami oleh siswa.

Faktor keempat, yaitu peneliti terkendala oleh keterlambatan subjek, pada saat pelatihan.Sebelumnya peneliti sudah mengingatkan subjek saat prates tentang jadwal pelatihan, dan dengan menginformasikan melalui pesan singkat agar diharapkan bisa datang tepat waktu. Hal itu tentunya, berdampak pada jadwal pelatihan yang mengakibatkan beberapa materi kurang maksimal saat disampaikan oleh trainer, sehingga subjek juga kurang maksimal dalam menyerap ilmu yang diberikan.

Berdasarkan tinjauan peneliti, mengenai jawaban-jawaban subjek, baik itu pada skala ataupun saat wawancara ditemukan, bahwa sebagian besar subjek kurang mampu melakukan pengaturan waktu dengan baik, karena adanya kesenjangan waktu antara rencana dan kinerja aktual, yang dipengaruhi oleh motivasi internal yang rendah. Senecal dkk., (1995) mengatakan prokrastinasi lebih dari sekedar problem manajemen waktu, tetapi motivasi internal. Senada dengan hal tersebut, Tandok (2008) menyatakan, 
bahwa aspek psikologis seperti rendahnya kontrol diri, penghargaan diri, motivasi, dan perfeksionisme dalam mengerjakan tugas dapat dikaitkan dengan sikap seorang maha-siswa terhadap tugas (attitude toward behavior). Sebagaimana yang diungkapkan Hayyinah (2004), bahwa lemahnya psikis individu, yaitu ketika prokrastinasi terjadi karena adanya motivasi yang rendah, irasional dan malas. Tiga sikap ini adalah indikasi rendahnya tingkat religiositas yang dimiliki individu.

Namun, melihat kenyataan dilapangan, subjek penelitian sebenarnya sudah mampu mempraktekkan shalat dengan teratur sebelum pelatihan, begitupula setelah diberikan pelatihan. Hanya saja ini menurut peneliti ini baru berdampak pada tataran koginitf subjek saja, seperti yang diungkapkan Ferrari dkk (1995) yang menyatakan bahwa siswa seringkali ingin melakukan perilaku belajar tetapi hanya berhenti sampai di tataran kognitif saja dan cenderung melakukan kebalikannya ketika ia tidak mampu bersikap asertif pada situasi sekelilingnya. Perlu dikembalikan dan diperhatikan kembali, bahwasanya cara pandang individu terhadap keberadaan agama yang mempengaruhi tinggi atau rendahnya tingkat religiositas yang pada akhirnya membentuk sikap dalam kehidupannya termasuk kehidupan akademiknya (Hayyinah, 2004).

Merujuk pada jawaban subjek tentang kebermanfaatan pelatihan shalat ini, bahwa sebagian besar subjek merasa pelatihan ini cukup bermanfaat dan dapat menimbulkan kesadaran baru, terutama membuat subjek lebih ikhlas dan termotivasi lewat ilmu baru yang diberikan. Sehingga hal ini tentunya memiliki peran dalam membantu proses belajar subjek, untuk mengendalikan diri dalam situasi-situasi yang merangsang timbulnya prokrastinasi akademik, yang tentunya hal tersebut butuh waktu dan penelitian yang lebih lama dan mumpuni, sesuai dengan yang peneliti ungkapkan pada faktor yang mempengaruhi hasil penelitian di paragraf sebelumnya.

Sehubungan dengan hasil penelitian secara kuantitatif yang menunjukkan tidak adanya pengaruh pelatihan shalat untuk menurunkan prokrastinasi akademik. Namun demikian, secara data wawancara yang telah dilakukan, sebagian besar subjek merasa pelatihan shalat ini bermanfaat dalam membentuk kesadaran baru mereka tentang betapa besar manfaat dan pentingnya shalat, tidak hanya ditinjau dari sekedar ibadah saja, melainkan bisa diterapkan dalam 
semua aspek kehidupan, seperti dalam kehidupan akademik.

Terkait dengan hal tersebut tentunya sebuah penelitian tidak selamanya sempurna. Oleh sebab itu, berdasarkan hasil analisis yang peneliti lakukan terhadap penelitian ini, peneliti menemukan beberapa kekurangan, seperti proses penelitian yang sebentar, sehingga perlu adanya penelitian lanjutan, pengontrolan individu subjek hanya terbatas pada lembar kerja yang diberikan pada saat pelatihan, dan randomisasi subjek penelitian yang kurang efektif.

\section{SIMPULAN DAN SARAN}

\section{Simpulan}

Berdasarkan hasil penelitian dan pembahasan pada bab sebelumnya, maka dapat disimpulkan bahwa hipotesis yang diajukan dalam penelitian ini ditolak, dikarenakan tidak adanya pengaruh pelatihan shalat untuk menurunkan prokrastinasi akademik pada mahasiswa. Meskipun demikian, hasil wawancara menunjukkan bahwa mahasiswa merasa merasa pelatihan shalat ini bermanfaat dalam membentuk kesadaran baru mereka tentang betapa besar manfaat dan pentingnya shalat, tidak hanya ditinjau dari sekedar ibadah saja, melainkan bisa disinkronkan dalam semua aspek kehidupan, seperti dalam kehidupan akademik.

\section{Saran}

Ada dua saran. Saran pertama adalah saran untuk instansi. Instansi tempat dilaksanakannya penelitian yaitu " $Y$ " Indonesia terkhusus bagi Fakultas diharapkan dapat memperhatikan mahasiswanya yang belum lulus melebihi target, yaitu mahasiswa yang telah menempuh pendidikan S-1 lebih dari empat tahun. Bentuk perhatian tersebut bisa dengan melakukan kegiatan bersama, terkait hal-hal yang dapat menumbuhkan motivasi dan kesadaran mahasiswa, terutama kegiatan yang bersifat religius, dan memotivasi agar mahasiswa termotivasi dalam perjalanan kuliah yang mereka tempuh dan harus diselesaikan secara efektif.

Saran berikutnya adalah saran untuk peneliti selanjutnya. Peneliti selanjutnya hendaknya memperhatikan faktorfaktor dan kelemahan-kelemahan dalam penelitian yang sudah dipaparkan dalam pembahasan sebelumnya. Selain itu, perlu juga diperhatikan pengontrolan subjek secara tegas dan tepat, dikarenakan mahasiswa yang mengalami prokrastinasi akademik, terutama mahasiswa yang kuliah lebih dari empat tahun 
memiliki tingkat kesulitan dalam mengontrolnya, mulai dari manajemen waktu, dan perjanjian yang dilakukan. Kemudian analisis kualitatif yang dilakukan harus lebih rinci dalam menangkap sebab-sebab mahasiswa melakukan prokrastinasi akademik. Selain itu, untuk alat ukur prokrastinasi akademik dirasa harus lebih variatif dalam menggambarkan prokrastinasi akademik yang dialami mahasiswa.

\section{DAFTAR PUSTAKA}

Akinsola, M.K., Tella, A.,\& Tella, A. (2007).Correlates of Academic Procrastination and Mathematics Achievement of University Undergraduate Students. Eurasia Journal of Mathematics, Science \& Technology Education, 3(4), 363-370.

Al-Fauzan, S.F. (2005).Al-Mulakhkhash Al-Fighi(Ringkasan Fikih Lengkap). Jakarta : Darul Falah.

Al-Ikhwani, F. (2012). Dahsyatnya 7 Sunnah. Surakarta : Ziyad Visi Media.

Asikhia, O.A. (2010). Academic Procrastination ini Mathematic Causes, Dangers, and Implications of Counseling for Effectie Learning. Canadian Center of Science and Education, 3 (3), 205-210.
Ferrari, J.R., Johnson,J.L \& McCown, W.G. (1995). Procrastination and Task Avoidance: Theory, Research and Treatment. New York: Plenum Press.

Haryanto, S. (2005). Psikologi Shalat. Yogyakarta : Pustaka Pelajar

Hayyinah. (2004). Religiusitas dan Prokrastinasi Akademik Mahasis-wa. Jurnal Psikologika, 17, 31-41.

Latipun. (2010). Psikologi Eksperimen. Malang : UMM Press.

Muhid, A. (2009). Hubungan antara SelfControl dan Self Efficacy dengan Kecenderungan Perilaku Prokrastinasi Akademik Mahasiswa Fakultas Dakwah IAIN Sunan Ampel Surabaya. Jurnal Ilmu Dakwah, 18 (1), 577-588.

Munandar, A.S. (2001). Psikologi Industri dan Organisasi. Jakarta : UI Press.

Ancok, D. \& Suroso, F.N. (2011). Psikologi Islami: Solusi Islam atas Problem-problem Psikologi. Yogyakarta: Penerbit Pustaka Pelajar.

Rumiani.(2006). Prokrastinasi Akademik Ditinjau dari Motivasi Berprestasi dan Stres Mahasiswa. Jurnal Psikologi Universitas Diponegoro, 3, 37-48.

Senecal, C., Koestner, R., \& Vallerand, R.J. (1995). Self Regulation and 
Academic Procrastination. The Journal of Social Psychology, 135 (5), 607-619.

Siswanto, F.Z. (2013). Hubungan Antara kedisiplinan Melaksanakan Sholat Wajib dengan Prokrastinasi Akademik pada Mahasiswa di
Fakultas Farmasi Universitas Ahmad Dahlan.Empathy Jurnal Fakultas Psikologi, 2 (1), 1-17.

Tondok, Marselius, \& Ristyadi, (2008). Prokrastinasi dan niat membeli skripsi. Anima Indonesia Psychological Journal, 24 (1),76-87. 